\title{
ESTRATÉGIAS FOCADAS NA REDE DE VALOR: UMA ANÁLISE DAS EMPRESAS PRODUTORAS DE EVENTOS
}

\author{
STRATEGIES FOCUSING ON VALUE NETWORK: AN ANALYSIS OF EVENT \\ PRODUCTION COMPANIES
}

\section{ESTRATEGIAS ENFOCADAS EN LA RED DE VALOR: UN ANÁLISIS DE LAS EMPRESAS PRODUCTORAS DE EVENTOS}

\author{
Marcos Roberto Piscopo \\ Doutor em Administração pela Faculdade de Economia, Administração e Contabilidade da \\ Universidade de São Paulo - FEA/USP \\ Professor da Fundação Getulio Vargas - FGV \\ E-mail: piscopo@piscopo.com (Brasil)
}

\section{Felipe Mendes Borini}

Doutor em Administração pela Faculdade de Economia, Administração e Contabilidade da Universidade de São Paulo - FEA/USP

Professor da Escola Superior de Propaganda e Marketing - ESPM

E-mail: fborini@espm.br (Brasil)

\section{Moacir de Miranda Oliveira Junior}

Doutor em Administração pela Universidade de São Paulo - USP

Professor da Faculdade de Economia, Administração e Contabilidade da Universidade de São Paulo

- FEA/USP

E-mail: miradaoliveira@ usp.br (Brasil) 


\title{
ESTRATÉGIAS FOCADAS NA REDE DE VALOR: UMA ANÁLISE DAS EMPRESAS \\ PRODUTORAS DE EVENTOS
}

\section{RESUMO}

O objetivo do artigo é mostrar que as empresas que competem em setores dinâmicos não o fazem com uma única estratégia. Em vez disso, as empresas buscam estratégias baseadas tanto na cadeia de valor como na rede de valor. Foi realizado um levantamento com 47 empresas de evento sediadas na cidade de São Paulo. Descobrimos cinco grupos distintos de empresas que seguiam estratégias diferentes. Os resultados reforçam a hipótese e o Modelo Delta de Hax e Wilde II (2001), particularmente no caso do setor de eventos, em que as empresas estão migrando para estratégias baseadas na rede de valor. As contribuições do estudo para a gestão estão relacionadas ao desafio das empresas de evento aprender a adotar diferentes posições estratégicas, baseadas tanto na cadeia de valor quanto na rede de valor, como meio de conquistar e de manter as vantagens competitivas em mercados dinâmicos.

Palavras-chaves: Rede de Valor; Modelo Delta; Estratégia Organizacional.

\section{STRATEGIES FOCUSING ON VALUE NETWORK: AN ANALYSIS OF EVENT PRODUCTION COMPANIES}

\begin{abstract}
The purpose of this article was to demonstrate that companies which compete within dynamic industries do not only adopt a single strategy. Instead, they pursue a number of strategies focusing on the value net rather than on the value chain. We carried out a survey with 47 event-planning firms based in the City of Sao Paulo and we have discovered five distinct groups of firms pursuing different strategies. Our findings support our hypothesis for the searched companies and also demonstrate how the Delta Model by Hax and Wilde II (2001) is useful to explain companies' strategic configuration. Particularly within the event industry, we have observed that companies are migrating to strategies based upon the value net. This study contributes to managing approaches concerning the challenges faced by event firms when learning how to adopt different strategic positions based upon both the value network and the value chain, in order to obtain and sustain competitive advantages in dynamic markets.
\end{abstract}

Keywords: Value Net; Delta Model; Strategic Management.

Revista Ibero-Americana de Estratégia - RIAE, São Paulo, v. 9, n. 1, p. 152-181, jan./abr. 2010. 
Marcos Roberto Piscopo, Felipe Mendes Borini \& Moacir de Miranda Oliveira Junior

\section{ESTRATEGIAS ENFOCADAS EN LA RED DE VALOR: UN ANÁLISIS DE LAS EMPRESAS PRODUCTORAS DE EVENTOS}

\section{RESUMEN}

El propósito de este artículo es mostrar que las empresas que compiten dentro de las industrias dinámicas no lo hacen con una única estrategia. En vez de eso, las empresas buscan estrategias basadas tanto en la cadena de valor como en la red de valor. Se realizó una encuesta con 47 empresas de eventos con sede en la ciudad de São Paulo. Descubrimos a cinco grupos distintos de empresas que seguían diferentes estrategias. Los resultados refuerzan la hipótesis y el Modelo Delta de Hax y Wilde II (2001), particularmente en el caso del sector de eventos, en que las empresas están migrando para estrategias basadas en la red de valor. Las contribuciones del estudio para la gestión se relacionan con el desafío para que las empresas de evento aprendan a adoptar diferentes posiciones estratégicas, basadas tanto en la cadena de valor como en la red de valor, como medio de conquistar y mantener las ventajas competitivas en los mercados dinámicos.

Palabras-clave: Red de Valor; Modelo Delta, Estrategia Organizacional.

Revista Ibero-Americana de Estratégia - RIAE, São Paulo, v. 9, n. 1, p. 152-181, jan./abr. 2010. 


\section{INTRODUCTION}

The business arena has been directly affected by transformations occurring at both external and industrial levels, which deeply impact companies' performance. Therefore, organizations are required to develop more effective ways of building and sustaining advantages over competitors. Nowadays, the strategic orientation is seen as a surviving factor in global economy since it relates to the ethos a company competes in the marketplace.

The Brazilian event industry has been growing significantly and it has recently played an important role in the country's economy. In 2001, a research conducted by Forum Brasileiro de Convention \& Visitors Bureau (FBC\&VB), Serviço Brasileiro de Apoio as Micro e Pequenas Empresas (SEBRAE), and Consultoria Turística Integrada (CTI) discovered that this industry accounts for $3.1 \%$ of Brazil's Gross Domestic Product (GDP) which corresponds to R $\$ 37$ billion. Other relevant findings were: (1) the event industry offered 80 million jobs, and (2) it contributed $\mathrm{R} \$ 4.2$ billion for taxes. According to SEBRAE's president, the world event market is responsible for more than US $\$ 4,000$ billion in annual revenue, employing nearly 255 million people, and capable of absorbing another 100 million more.

The event production industry leverages tourism flows and also aids the development of correlated industries such as transportation, food, staff services, etc. Zanella (2003) pointed out that nearly $40 \%$ of tourism flows represent business trips while around $60 \%$ relate to leisure. For that reason, we see an increasing number of fairs, conferences, sports events, expositions, business meetings, among many others.

While reducing the distance among markets, globalization brings people together and allows cultural exchange and learning, which can be translated into business opportunities for both the event and tourist industries. Lofgren (1999) suggests that people are obsessed with great and memorable experiences. Subsequently, a new day is born and events are the means by which memories take place. As observed by Pine and Gilmore (1999), organizations use events to increase an experience lived in a particular moment. According to Goldblatt (2000), age, technology, income and time are the dimensions that influence the growth of the event industry.

As the event industry boosts the performance of correlated industries, the latter must significantly add value to the former's products and services. To survive and prosper, companies operating downstream and upstream highly depend on the success of event production organizations. Then, they can be considered as complementary businesses and the need for understanding how they compete drives the desire of investigating how they formulate competitive strategies and how they implement them.

Revista Ibero-Americana de Estratégia - RIAE, São Paulo, v. 9, n. 1, p. 152-181, jan./abr. 2010. 
Marcos Roberto Piscopo, Felipe Mendes Borini \& Moacir de Miranda Oliveira Junior

The traditional models supporting strategy formulation usually follow Porter's (1980) typology. However, the current business landscape imposes new challenges to companies, and because of that, strategies based upon the value chain are not likely to be sufficient. Since event production companies are not totally independent from other companies integrating the business system, it is reasonable that they go beyond the competitive paradigm and consider competing while cooperating. In doing so, companies should not reject the idea of building relationships with customers, suppliers, supporting businesses and even competitors.

Due to the complexity of the business environment and the dynamics of the event industry it seems to us that there is an unanswered question regarding how event production companies formulate competitive strategies. Hence, this study aims to answer the following research question: What is the dynamics of the event industry and how do event production companies compete?

We start by presenting the need for alternative strategic options to compete in the current business environment. Later on, we present some perspectives on strategy and the cost versus differentiation dilemma. The theoretical background included within this study also covers the strategic thinking evolution by explaining the emergence of some typologies of strategy. We then describe the methodological aspects for data collection and analyses. Finally, we present the conclusions, contributions, and limitations of this study.

\section{THEORETICAL BACKGROUND AND HYPOTHESIS}

Scholars and practitioners have suggested a number of definitions for strategy, although none has been universally accepted. Despite this fact, it is important to highlight that strategy differs from the need for having strategy (Ansoff, 1965). The literature on strategic management shows two different perspectives. The first one defines strategy by considering a single dimension, which means that strategy is understood as a series of plans the company adopts to achieve its objectives and carry out its mission. Some authors that defend this position are Chandler (1962), Ansoff (1965), Andrews (1971) and Wright et al. (1992).

The second perspective views strategy as something encompassing several dimensions, which considers not only a deeper analysis of the theme but also aspects relevant to strategy formulation and implementation. Hax and Majluf (1996) and Mintzberg et al. (2000) are a number of scholars who share this point of view.

Revista Ibero-Americana de Estratégia - RIAE, São Paulo, v. 9, n. 1, p. 152-181, jan./abr. 2010. 
Strategies Focusing on Value Network: An Analysis of Event Production Companies

\subsection{THE COST VERSUS DIFFERENTIATION DILEMMA}

Porter (1980) was neither the first, nor will be the last, scholar to study strategy; however, his approach to strategy has leveraged this field of study. The creation of the generic competitive strategies revolutionized the strategic management, and since 1980 there has been an increasing interest in strategy. Therefore, some scholars have supported Porter's ideas while others have criticized them. Criticisms likely occurred when Porter (1980, p. 41) stated that "a firm that is stuck in the middle is in an extremely poor strategic situation". So, the firm must define its strategic positioning as either low cost or differentiation. According to Porter (1996, p. 68), "a strategic position is not sustainable unless there are trade-offs with other positions. Trade-offs occur when activities are incompatible." This suggests that by emphasizing one thing the company weakens another. Moreover, trade-offs force the company to make choices but protect it against the actions of repositioning and trading; surfacing from inconsistencies in image or reputation, activities themselves, and limits on coordination and control (Porter, 1996).

Due to the large dissemination of Porter's ideas $(1980,1985,1996)$ and their importance to the field of strategy, some scholars made significant comments. For instance, Hill (1988, p. 401) declared that Porter's (1980) generic strategies are flawed in two aspects: "(1) differentiation can be a means for firms to achieve an overall low cost position, and (2) there are many situations in which establishing a sustained competitive advantage requires the firm to simultaneously pursue both low cost and differentiation strategies because in many industries there is no unique low cost position”.

Other relevant studies regarding Porter's competitive strategies, whose findings are important to the cost versus differentiation dilemma, have been conducted by Hall (1980), Hambrick (1983), Dess and Davis (1984), White (1986), Jones and Butler (1988), Kim and Lim (1988), Murray (1988), Marques, Lisboa, Zimmerer and Yasin (2000) and Hitt, Ireland and Hoskisson (2001).

Among the previous list of contributions, we would like to highlight that a number of scholars believe it is possible to simultaneously pursue both low cost and differentiation, such as Hill (1988), Murray (1988), and Hitt, Ireland, and Hoskisson (2001). To explore this issue, we first study some typologies of strategy and suggest grouping them into two categories as shown in Table 1.

Revista Ibero-Americana de Estratégia - RIAE, São Paulo, v. 9, n. 1, p. 152-181, jan./abr. 2010. 
Marcos Roberto Piscopo, Felipe Mendes Borini \& Moacir de Miranda Oliveira Junior

Table 1 - Typologies of Strategy.

\begin{tabular}{|c|c|}
\hline Value Chain Oriented Strategies & Value Net Oriented Strategies \\
\hline Generic Competitive Strategies - Porter (1980) & Strategic Triangle - Ohmae (1982) \\
\hline Defining the Business - Abell (1980) & Co-opetition - Brandenburger \& Nalebuff (1996) \\
\hline Value Disciplines - Treacy \& Wieserma (1995) & Dusiness Landscape - Ghemawat (2000) \\
\hline Value Migration - Slywotzky (1996) & Dodel - Hax \& Wilde II (2001) \\
\hline
\end{tabular}

Generic Competitive Strategies.

Porter (1980) has built a noticeable reputation in the field of strategy - his ideas were released when the business world was beginning to face problems requiring innovative solutions. Therefore, his initial work concerning industrial analysis gained notoriety and has been adopted all over the world. He defended that competition does not depend exclusively upon the behavior of competitors but on the five basic competitive forces he named "forces driving competition" which are; rivalry among existing firms, threat of new entrants, threat of substitute products and services, bargaining power of suppliers and bargaining power of buyers (Porter, 1980).

Besides determining the degree of competition within industries, these five forces have the potential to leverage the return of investments the company makes and are also of great importance to the strategy formulation process. These competitive forces influence, and are influenced, by those organizations in the industry. As a result of that, a company that identifies the sources of these competitive forces has a better chance to attain a position in which it can protect itself against them or influence them in its favor. To make it happen, there are three generic strategies a company can employ to create a sustainable position and outperform competitors in the industry for the sake of precision: overall cost leadership, differentiation, and focus (Porter, 1980).

\subsection{DEFINING THE BUSINESS}

Abell (1980) disagreed with the two-dimensional concept of product/market strategy to define the business. To replace it, he suggested a three dimensional approach involving customer groups, customer functions, and technologies. In accordance with Abell (1980, p. 17) a business can

Revista Ibero-Americana de Estratégia - RIAE, São Paulo, v. 9, n. 1, p. 152-181, jan./abr. 2010. 
also be defined through three distinct measures: “(1) scope, (2) differentiation of the company offerings, amongst themselves, across segments, and (3) differentiation of the company offerings from those of competitors".

Therefore, scope and differentiation should be understood in terms of customer groups served, customer functions served, and technologies utilized. As scope and differentiation are related to each other, there are three possibilities for defining the business: focused strategy, differentiated strategy, and undifferentiated strategy. Since the options focused, differentiated, and undifferentiated exist in customer groups, customer functions, and technology dimensions, choices can be classified into 27 ( 3 X 3 X 3) distinct positions, as follows: (1) focused, differentiated, or undifferentiated across customer groups, (2) focused, differentiated, or undifferentiated across customer functions, and (3) focused, differentiated, or undifferentiated across technologies (Abell, 1980).

\subsection{VALUE DISCIPLINES}

Treacy and Wieserma (1995) created a typology of strategy based upon the value added to customers. They observe that the company's success results from selling to customers exactly what is ordered, by enhancing the level of excellence of a specific component that competitors are not able to replicate. These components are usually; price, time, differentiated support and quality. According to the component a company intends to emphasize, it must make a strategic choice between the market disciplines: specifically, operational efficiency, product leadership, and customer intimacy.

A company pursuing the operational efficiency strategic option focuses on the market segment seeking the highest value for the total cost of ownership. This includes a combination of price, quality, and facility in serving customers. Separately, a company adopting the product leadership strategy concentrates on the market segment looking for the most updated product and service. To do so, the company searches for what is yet unknown. Finally, to pursue the customer intimacy strategic position, a company focuses on the segment of customers needing customized solutions to meet specific demands (Treacy \& Wiserma, 1995).

Revista Ibero-Americana de Estratégia - RIAE, São Paulo, v. 9, n. 1, p. 152-181, jan./abr. 2010. 
Marcos Roberto Piscopo, Felipe Mendes Borini \& Moacir de Miranda Oliveira Junior

\subsection{VALUE MIGRATION}

Value migration is an outside-in approach to business strategy, beginning with customers and ending with the company. The company should focus on the environment so that it can build the required capacity and ascertain which direction to follow. The concept of value migration allows the company to identify where the value comes from and where it is headed. Thus, by understanding the value migration process, the company may have the ability to discover what customers will need in future, how to offer that ahead of its competitors, and how to identify future potential competitors (Slywotzky, 1996).

The value migration may impact a business division of a firm, the entire firm, or in an event of the whole industry as customers select which business designs better satisfy their needs. The business design is an overview of how a company chooses which customers to serve, structure and differentiate its offers from those of competitors, selects which activities to execute internally and which to outsource, arranges its resources, approaches the market, delivers benefits to customers and obtains profits (Slywotzky, 1996).

\subsection{STRATEGIC TRIANGLE}

Ohmae (1982) argues that the success of a business is more related to the executive's state of mind than the rigorous strategic analysis. Although technical expertise is essential to the strategy formulation process, the latter emerges from insights that are seen to be beyond the conscious analysis. Subsequently, the formulation of a business strategy should consider the company itself, the customer, and the competition. These three Cs represent an organization with specific interests and objectives that together form the Strategic Triangle. Therefore, a strategy can be understood as the means by which a company attempts to differentiate its offerings from those of competitors by leveraging its strengths with the purpose of meeting customers' needs. However, strategy development and implementation depend upon how the company deals with the main parties, to be more precise, with the company itself, the customer, and the competition (Ohmae, 1982).

According to the Strategic Triangle there are distinct strategic options a company can pursue, as follows: customer-based strategies, corporate-based strategies, and competitor-based strategies. Customer-based strategies are those employed to serve different customer groups since they have different needs and the company may not have the ability to meet them all with the same level of effectiveness. Corporate-based strategies focus on leveraging firm's strengths, especially

Revista Ibero-Americana de Estratégia - RIAE, São Paulo, v. 9, n. 1, p. 152-181, jan./abr. 2010. 
those that are essential to succeed in the industry. Competitor-based strategies seek to find out the sources of differentiation in functions involving purchasing, design, engineering, sales and support (Ohmae, 1982).

\subsection{CO-OPETITION}

By taking business as a game, it becomes necessary to identify the players and which role they perform. Traditionally, doing business involves dealing with customers and suppliers; however, there is an important facilitator who is often forgotten, namely, the complementor. A complementor is a relevant player who provides complementary offerings rather than competing products and services. Therefore, a complementor has strong potential to put the company on the route to success (Brandenburger \& Nalebuff, 1996).

Considering complementors as a different way of thinking about business, a company should observe the possibility of increasing the market in size rather than just competing for share in a consolidated market. Consequently, the key is to ascertain the expansion of the market through the development of new complementors or making the existing ones more affordable. To realize this, it is crucial not only to understand but also to explore the role of customers, suppliers, competitors and complementors and the interdependence among them. This is how the value net works (Brandenburger \& Nalebuff, 1996).

\subsection{BUSINESS LANDSCAPE}

Traditional structures employed to analyze industries involve the supply versus demand concept and the forces driving competition. Despite the importance of industry analysis, the business landscape approach aims to explore how it impacts the company's most complex relationships. This aids the process of mapping different business models and the sources of their profitability. Therefore, the major challenge is to put the company into the landscape that may allow the best return. Additionally, mapping landscapes does not mean merely identifying whether or not a company earns above average returns but also discovering why and how this occurs in order to take advantage (Ghemawat, 2000).

Revista Ibero-Americana de Estratégia - RIAE, São Paulo, v. 9, n. 1, p. 152-181, jan./abr. 2010. 
Marcos Roberto Piscopo, Felipe Mendes Borini \& Moacir de Miranda Oliveira Junior

\subsection{THE DELTA MODEL}

The Delta Model by Hax and Wilde II (2001) is a new approach to business strategy development and is specifically addressed to the networked economy. It represents a structure developed to face the most complex economic forces that arise from the competitive environment. The Delta Model central issue is the strategy, both for the old and for the new economy. However, instead of formulating strategies considering solely the competition, the Delta Model emphasizes the bonding that can be achieved among customers, suppliers, competitors, substitutes, and complementors (firms that can deliver products and services which can potentially enhance company offerings). The Delta Model considers three distinct options of strategic positioning, which are displayed through a triangle (Figure 2): Best Product (BP), Total Customer Solutions (TCS), and System Lock-In (SLI). These strategic choices define how the company competes and serves customers in its marketplace.

\subsection{THE BEST PRODUCT STRATEGIC OPTION}

The best product strategic option is based upon the traditional forms of competition which concern only low cost and differentiation dimensions. These dimensions were already introduced by Porter (1980) and they refer exclusively to one of the possible strategic positions of the Delta Model. In this case, the most important economic drives are focused on the value chain of the product or service. Firms that pursue this strategic positioning usually want to improve the efficiency of their own supply chain, and their products tend to be standardized. Customers can be considered faceless once they are generic and served through mass distribution channels. Innovation is focused on internal product development and its primary objective is to renew the product line. The best product arises as a strategic option from the industrial era and it is the strategy adopted for the majority of firms nowadays. It is important to notice that businesses that compete through best product strategy attract their customers by the intrinsic characteristics of their products, and as result the degree of customer bonding is very small. Therefore, the customer leaves as soon as he finds a newer, more superior, product in the marketplace (Hax \& Wilde II, 2001).

Revista Ibero-Americana de Estratégia - RIAE, São Paulo, v. 9, n. 1, p. 152-181, jan./abr. 2010. 
Figure 1 - Business Model: three distinct strategic options.

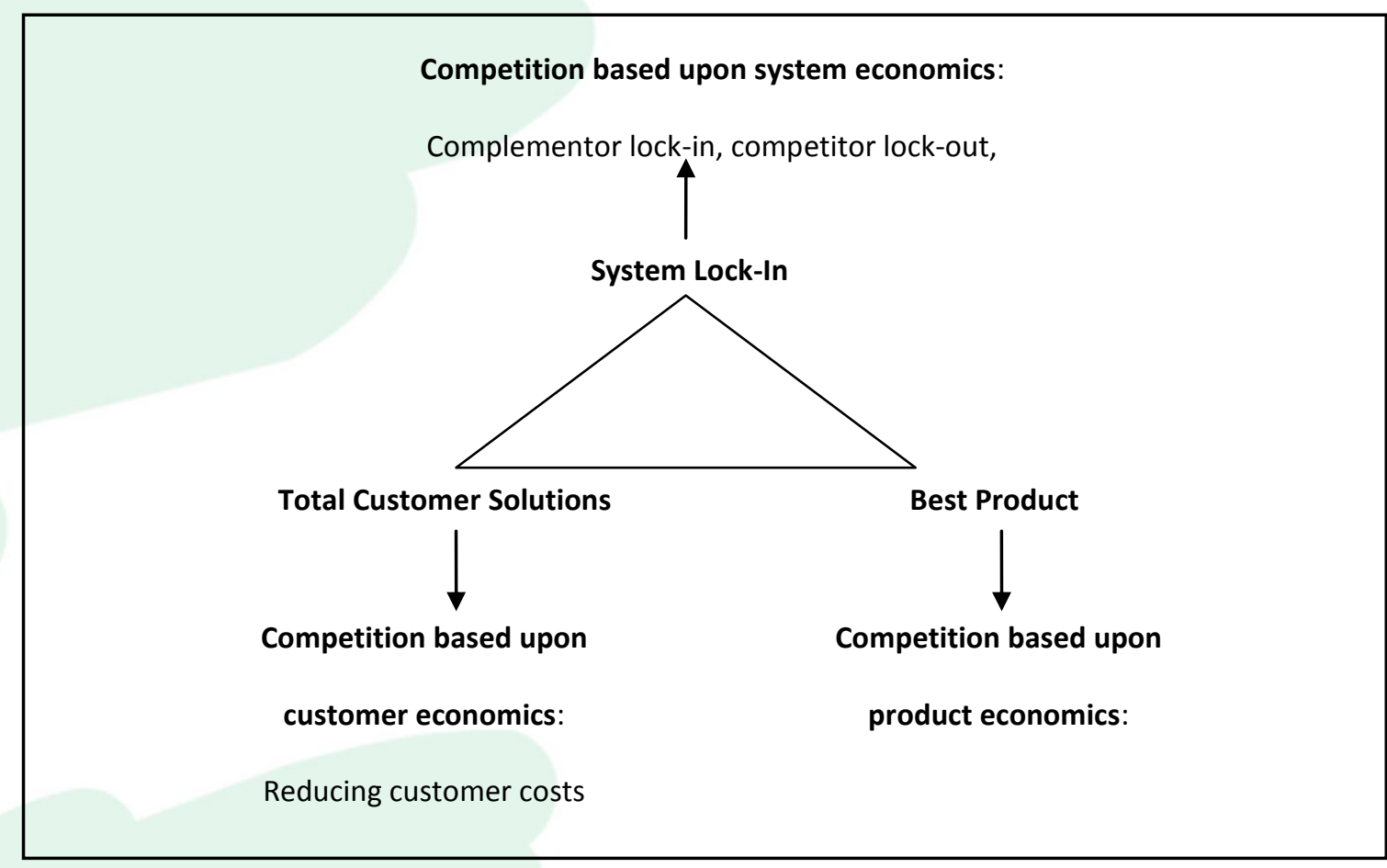

Source: Hax et al. (2001, p. 10).

\subsection{THE TOTAL CUSTOMER SOLUTION STRATEGIC OPTION}

The Total Customer Solution strategic option is based upon establishing a strong bond with customers. Instead of serving customers through mass distribution channels, total customer solutions players seek to learn as much as possible about their customers in order to provide customized solutions. Rather than focus on product economics, they are based upon customer economics. Instead of providing single products, they offer a bundle of product and services to meet the majority of customer needs. Relating to the supply chain management, Total Customer Solution players focus their efforts to combine their competencies with that of their customers. The internet plays an important role to connect the company with its customers and its suppliers. Rather than simply renew their product lines, they focus to initiate product development in cooperation with their target customers. This close relationship with customers leads to mutual learning where the customer learns more about the offer and the company learns more about customers business. This kind of relationship usually brings additional parties that complement the product bundle. Hence, customization and mutual learning drive bonding which is not easy to be imitated by competitors. The adoption of the Total Customer Solutions strategic option requires an appropriated 
Marcos Roberto Piscopo, Felipe Mendes Borini \& Moacir de Miranda Oliveira Junior

segmentation of the customer base, including a clear set of priorities in order to identify the importance of each potential customer. It is also necessary to have a deep and personal knowledge of the client's business and an understanding of how it relates to your own business. This strategic position requires an individual value proposition which is tailor-made for each customer. Moreover, the measure of performance is customer market share (share of wallet) instead of market share that is used for the Best Product players. There are three different methods to reach the Total Customer Solutions position: (1) Redefining Customer Experience, (2) Horizontal Breadth, and (3) Customer Integration (Hax \& Wilde II, 2001).

The Redefining Customer Experience approach to Total Customer Solutions is based on changing the relationship with the customer from the moment of acquisition to the completion of lifetime ownership. It requires an understanding of how customers interact with the product and redefine their experience in order to increase their own benefits. Experiences can only be acquired and evaluated once the customer has purchased the product. Therefore, the company must build a relationship with the customer which cannot be limited to the transaction. The bonding allows the customer to learn more about the company and it helps him believe in the promised results (Hax \& Wilde II, 2001).

The Horizontal Breadth approach to Total Customer Solutions is focused on providing a complete set of products and services to better satisfy customer needs. The goal of the horizontal breadth is to maximize customer economics and fortify customer bonding through the integration and customization of a wide scope of related products and services. A bundle of products is very important and can create bonding opportunities. However, horizontal breadth goes beyond bundling, because when bundling alone leads to volume discounts, horizontal breadth optimizes services by customizing and integrating a related set of products in order to better meet customer needs when comparing it to the purchase and use of the separate products. Hence, bundling can create bonding opportunities (Hax \& Wilde II, 2001).

The Customer Integration method in achieving Total Customer Solutions aims to outsource or facilitate activities usually executed by the customer. Players acting like this assume activities customers are known to perform. Firms following the Customer Integration perform these activities more efficiently or effectively than the customer in order to increase customer economics through added value or cost advantage. Therefore, it can create a custom habit between the company and the customer which is more than simply operational efficiency and cannot easily be imitated by the competitors. Investments are made with time and resources by the business and the customer in order to tailor a product and the ways it can be used and processed by the customer. This generates

Revista Ibero-Americana de Estratégia - RIAE, São Paulo, v. 9, n. 1, p. 152-181, jan./abr. 2010. 
switching cost and the more the customer uses the product the more the switching cost increases. Hence, customer integration is different from outsourcing, once an outsourcing player does not achieve competitive advantage through bonding, then it also does not create switching cost (Hax \& Wilde II, 2001).

\subsection{THE SYSTEM LOCK-IN STRATEGIC OPTION}

The System Lock-In strategic option is based upon the overall architecture of the system and, as a result, it must consider the extended enterprise to create economic value which includes: the business, its customers, its suppliers, and its complementors. This position is the strongest way of bonding and one area deserves special attention: the complementor. According to Brandenburger and Nalebuff (1996, p. 18) "a player is your complementor if customers value your product more when they have the other player's product than when they have your product alone”. Similarly Hax and Wilde II (2001, p. 81) stated that "a complementor is not a competitor, or necessarily a supplier; it is a provider of products and services that enhance, directly or indirectly, our own offering". System Lock-In businesses aim to attract, satisfy, and retain customers through the attraction, satisfaction, and retention of complementors. The value of the system grows as the participation of its elements becomes more intense. This drives participants to an economic zone of increasing profitability. However, creating the Lock-In position requires the system to meet two essential conditions: (1) the existence of increasing marginal returns, and (2) external network effects. Increasing marginal returns demonstrates the way the value of the product or service grows with the increasing number of users and rate of usage. Network externalities reflect that attractiveness of the product does not depend on the intrinsic characteristics of the product itself, but rather on the investment made by the other participants, specially customers and complementors. There are three distinct forms to achieve the System Lock-In strategic option: (1) Proprietary Standard, (2) Dominant Exchange, and (3) Restricted Access (Hax \& Wilde II, 2001).

The Proprietary Standard approach to System Lock-In strategic option is based in the wide range of complementors that are built to work with its product. Therefore, if customers want to use these complementors, customers must use the Proprietary Standard. Achieving a Proprietary Standard requires the firm to satisfy two conditions. The first is to become a natural locus and interface in an open system. The second task, which is more difficult, relies in getting the full proprietary ownership of the standard, and as a result, take the biggest share of value the system will create (Hax \& Wilde II, 2001).

Revista Ibero-Americana de Estratégia - RIAE, São Paulo, v. 9, n. 1, p. 152-181, jan./abr. 2010. 
Marcos Roberto Piscopo, Felipe Mendes Borini \& Moacir de Miranda Oliveira Junior

The Dominant Exchange way to System Lock-In is focused on providing an interface between buyers and sellers, or between participants which intend to exchange information or products. Once a player has achieved this position it is very difficult to beat it. This interface becomes more valuable with the increasing number of people who go there to seek, buy, or even exchange items. The value of the interface grows with use, and it is likely that the leading exchange will dominate the market (Hax \& Wilde II, 2001).

The Restricted Access to System Lock-In strategic option seeks to deprive competitors from accessing the customer once the channels do not have the capacity to handle so many vendors. Following Hax and Wilde II (2001) proprietary standards and dominant exchange leads to bonding through customer lock-in and also competitor lock-out, which are at the extreme of the bonding continuum. However, the competitor lock-out generally comes through constrained distribution and supply chains.

Based upon the previously forms for strategic management we propose:

Central Hypothesis: In order to outperform competitors in the $21^{\text {st }}$ century, companies need to pursue different strategies, especially strategies based upon the value net (Total Customer Solutions and System Lock-In) rather than strategies based upon the value chain (Best Product).

\section{METHODOLOGY}

\subsection{DATA COLLECTION}

The exploratory study was chosen because of the lack of research within the field of event management, especially about strategic options. Our sample consisted of people involved in strategic management activities in event planning companies based in the City of Sao Paulo. Research participants were business owners, executives and event producer managers. We justify the participation of event producer managers because they perform crucial tasks to the strategic positioning of the firm, such as: event planning and execution. Due to the recent organization of the Brazilian event industry, no association, institute or union has a complete list of event planning companies. There is no list or ranking of these firms either. Therefore, we have combined the databases of the most important associations, institutes, and unions that list event planning companies based in the City of Sao Paulo as follows: (1) Associação Brasileira de Empresas de 
Eventos (ABEOC), (2) Associação Brasileira dos Centros de Convenções, Exposições e Feiras (ABRACCEF), (3) Fórum Brasileiro dos Convention \& Visitors Bureaux (FBC\&VB), (4) União Brasileira dos Promotores de Feiras (UBRAFE), (5) Associação de Marketing Promocional (AMPRO), and (6) Guia dos Fornecedores da Comunicação Meio \& Mensagem. After appropriated corrections the concluded list had 329 event planning companies.

The research was carried out through the application of a structured questionnaire with multiple choice questions which were always presented to the participants in the same sequence. We mailed the questionnaires and phone calls were made in order to track the return of questionnaires. Despite using trusted mailings, 51 questionnaires did not reach the potential participants because of several reasons according to Empresa Brasileira de Correios e Telégrafos, such as: changed address, unknown addressee, insufficient address, number does not exist, incorrect zip code, and refused address. Hence, the number of potential participants dropped to 278 . We have received 48 fully-answered questionnaires and the overall response rate to the survey was almost 17 percent.

\subsection{COMPANIES' PROFILE}

The profile analysis of the sample demonstrated that $89.4 \%$ of companies perform event organizing and executing activities. A total of $78.7 \%$ of firms performed project management and event planning tasks. Outsourcing activities tasks were executed by $68.1 \%$ of event businesses. Only $19.1 \%$ of event companies focused on selling products, and $25.5 \%$ performed other activities, such as: workmanship outsourcing, promotional actions, result oriented marketing, prize promotions, event consulting, and congress management.

A total of $44.7 \%$ of studied companies served customers around the country, and $23.4 \%$ of them competed internationally. We found that $21.3 \%$ of event firms served many provinces, and $19.1 \%$ had customers in several cities.

We discovered that $89.4 \%$ of studied firms produced business events and $57.4 \%$ of them organized educational events. Segments of social events and special events were served respectively by $34.0 \%$ and $31.9 \%$ of event organizing companies. A total of $29.8 \%$ of studied firms served the show business segment, while $25.5 \%$ of them produced other forms of events such as: sports events, private and public leisure events, agricultural events, etc. Only $8.5 \%$ of event planning businesses organized political events.

Revista Ibero-Americana de Estratégia - RIAE, São Paulo, v. 9, n. 1, p. 152-181, jan./abr. 2010. 
Marcos Roberto Piscopo, Felipe Mendes Borini \& Moacir de Miranda Oliveira Junior

Family members run a total of $59.6 \%$ of studied firms and $21.3 \%$ of them had mixed management (professional executives and family members). We have also discovered that only $17.0 \%$ of studied companies had professional management.

\subsection{VARIABLES}

First of all, we carried out a theory review in order to select a set of strategic variables that could allow us identify clusters. Moreover, it would help us to relate current event business strategies to Hax and Wilde II (2001) typology.

A previous version of the questionnaire was mailed to 7 individuals who have identical characteristics to that of the target-respondent group in order to improve the instrument for data collection and make its application more efficient. We attached a letter to the questionnaire and its primary objective was to both thank respondents and to ask them about certain aspects of the questionnaires, including: (1) time spent to answer the questions, (2) the existence of difficult to understand questions, (3) the existence of repetitive questions, (3) the length of the questionnaire, (4) the layout of the questionnaire, and (5) other comments.

The study of the strategies adopted by searched companies involved the analysis of variables that drive the business to a strategic positioning accordingly either to the value chain or to the value net. These variables are shown in Table 3.

\section{RESULTS}

We did not find high correlation coefficients but a number deserve our consideration and comments. Nevertheless, the correlation analysis is important because it allows us to infer relevant statements about the relationship of these variables, which supports the analysis, though it does not mean a causality relation.

The variables "economies of scale" and "in search of the best cost versus benefits relation" are moderately correlated $(\mathrm{p}<.01)$. In the event industry it is necessary to assign and integrate several unique suppliers. Despite the need for customized offerings, event planning businesses are used to establish some common platforms in order to take advantage of the economies of scale. Correlation between "economies of scale" and "technologic innovations" is significant $(\mathrm{p}<.05)$. We emphasize that, through technologic innovations, event planning firms can better manage their projects by saving time and resources, which are essential to translate projects into real events.

Revista Ibero-Americana de Estratégia - RIAE, São Paulo, v. 9, n. 1, p. 152-181, jan./abr. 2010. 
Strategies Focusing on Value Network: An Analysis of Event Production Companies

There is significant correlation $(\mathrm{p}<.01)$ between the variables "customer relationship" and "learn with customers". Separate from competing through superior products and services, establishing relationship with customers allows the company to better identify customer needs and as a result develop a customized solution for each case. This can be possible through the mutual learning where participants trust one another.

Variables "identify, attract, and retain complementors" and "find out which complementors add more value to the offering" are correlated $(\mathrm{p}<.01)$. Once the company has discovered which complementors adds value to its offering, it is necessary to develop methods to attract and retain them in order to establish an advantage. Thus, we shall use an event as an example taking place in an auditorium without a parking lot for guests. Certainly, they will be able to find a place to park their cars. However, there will be inconveniences: guests will have to walk to the parking lot to get their cars after the end of the show. A parking lot is a service not included in the project scope, but the event producer could better satisfy its customers by finding a parking lot (complementor), thereby offer parking attendants in front of the auditorium. This leads to a virtuous cycle of identifying which complementors make the offering more valuable to customers, and consequently it identifies, attracts, and retains specific complementors.

A significant correlation $(\mathrm{p}<.01)$ is noticed between variables "the firm, its suppliers, and its customers' involvement" and "customer relationship". Planning an event is a very complex process and it requires high expertise from the participants. The event production should not be limited to the internal supply chain management. Customer needs will be better understood and shall be met through the involvement of other participants: customer and suppliers that integrate the event value chain. This makes the development of an exclusive solution for each customer possible and explains the significant correlation $(\mathrm{p}<.05)$ between the variables "the firm, its suppliers, and its customers' involvement" and "complete and exclusive solutions".

We have discovered that the variables "standardized products and services" and "internal development based upon common platform" are significantly correlated $(\mathrm{p}<.01)$. It is understood that products and services standardized offerings are usually developed through internal processes and are based upon a common platform. Therefore, the company enjoys a cost advantage, besides the lower volume of investments to develop products and services. This often occurs in advertising materials designed for the agency's professionals and produced through standardized layouts and measures.

Variables "learn with customers" and "new ways of doing business" are significantly correlated $(\mathrm{p}<.01)$. The traditional forms of loyalty based upon products and services offering do

Revista Ibero-Americana de Estratégia - RIAE, São Paulo, v. 9, n. 1, p. 152-181, jan./abr. 2010. 
Marcos Roberto Piscopo, Felipe Mendes Borini \& Moacir de Miranda Oliveira Junior

not ensure customer satisfaction. The dynamic of the current competition shifts the direction of the rules governing loyalty. Nowadays customers drive the process, meaning that they will look for the company that better understands them and satisfies their needs. Therefore, in order to win a customer's loyalty a company must identify their preferences and values, which requires mutual learning and the undertaking of new methods of doing business.

There is significant correlation $(\mathrm{p}<.01)$ between the variables "satisfy customers through the firm, its customers, and its complementors" and "joint product innovation with customers". In this case the innovation process goes beyond the common platform often utilized for developing products. Customers might join the innovation process; however, a big contribution comes from the integration among the system's participants, especially complementors which can aggregate more value to the solution.

We have observed a significant correlation $(\mathrm{p}<.05)$ between the variables "support customers, suppliers, and complementors" and "satisfy the customer through the firm, suppliers, customers, and complementors". Information technology plays an important role for the business strategy implementation, and it becomes essential to integrate the participants that will develop the solution.

Variables "sell more to the same customers" and "identification, attraction, and retention of complementors" are significantly correlated $(\mathrm{p}<.05)$. In order to serve the event market, a firm can organize many small events for several customers, or it can produce many more events for the same customers. It can be possible, through the wide scope of offering, to have a more complete array of products and services.

\subsection{FACTORIAL ANALYSIS}

The reduction of the geographic space has as the main objective the selection of factors that can explain the variance of the sample in a more synthetic way than if we treat each variable separately. In doing so, it was possible to extract 7 factors that jointly explain 77 percent of the variance for the total sample.

Table 2 presents the matrix factors for the reduced geographic space after varimax axis orthogonal rotation.

Revista Ibero-Americana de Estratégia - RIAE, São Paulo, v. 9, n. 1, p. 152-181, jan./abr. 2010. 
Table 2 - Factors.

Discover which complementors aggregate more value to customers

Discover the cost drivers

Beneficiate all participants involved

Identification, attraction, and retention of complementors

Sell superior product and services

Firm, suppliers, customers, and complementors join the innovation

Customers join the innovation

Support relationship with customers and suppliers

Support relationship with customers, suppliers, and complementors

Involvement of the firm, suppliers, customers, and complementors teams

Satisfy the customer through the firm, suppliers, customers, and complementors

Involvement of the firm, suppliers, and customer teams

Complete and exclusive solutions

Internal development based upon common platform

Standardized products and services

More complete set of products and services

Extraction Method: Principal Component Analysis.

Rotation Method: Varimax with Kaiser Normalization

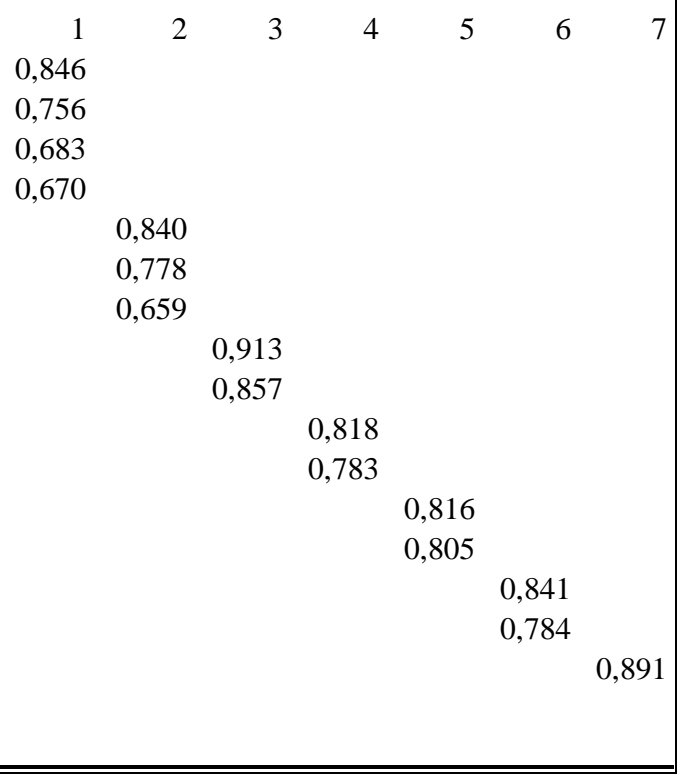

Source: Elaborated by the authors.

The data analysis allows us to make important inferences using the information provided by the factors' charge in order to help the interpretation of these factors formed by 24 strategic variables. Factors are explained accordingly to Table 3 and they are used to form strategic groups through the cluster analysis.

Table 3 - Factors Identification.

\begin{tabular}{|c|c|c|}
\hline 1 & $\begin{array}{c}\text { Discover which complementor aggregate more value to customers; } \\
\text { Discover cost drivers; } \\
\text { Beneficiate all participants involved; } \\
\text { Identification, attraction, and retention of complementors. }\end{array}$ & $\begin{array}{c}\text { Supply chain strategy based upon } \\
\text { value net }\end{array}$ \\
\hline 2 & $\begin{array}{c}\text { Sell superior products and services; } \\
\text { Customers joint the innovation. }\end{array}$ & $\begin{array}{c}\text { Innovation strategy based upon } \\
\text { value net }\end{array}$ \\
\hline 3 & $\begin{array}{c}\text { Support relationship with customers, suppliers, and complementors. } \\
\text { Suplions }\end{array}$ & $\begin{array}{c}\text { Customers strategy based upon } \\
\text { value net }\end{array}$ \\
\hline 4 & $\begin{array}{c}\text { Involvement of the firm, suppliers, customers, and complementors teams; } \\
\text { Satisfy the customer through the firm, suppliers, customers, and } \\
\text { complementors. }\end{array}$ & $\begin{array}{c}\text { Partners strategy based upon } \\
\text { value net }\end{array}$ \\
\hline
\end{tabular}

Revista Ibero-Americana de Estratégia - RIAE, São Paulo, v. 9, n. 1, p. 152-181, jan./abr. 2010. 
Marcos Roberto Piscopo, Felipe Mendes Borini \& Moacir de Miranda Oliveira Junior

\begin{tabular}{|c|c|c|}
\hline 5 & $\begin{array}{c}\text { Involvement of the firm, suppliers, and customers teams; } \\
\text { Complete and exclusive solutions. }\end{array}$ & $\begin{array}{c}\text { Customers strategy based upon } \\
\text { value chain }\end{array}$ \\
\hline 6 & $\begin{array}{r}\text { Internal development based upon common platform; } \\
\text { Standardized products and services. }\end{array}$ & $\begin{array}{c}\text { Low cost strategy based upon } \\
\text { value chain }\end{array}$ \\
\hline 7 & More complete set of products and services. & $\begin{array}{c}\text { Differentiation strategy based } \\
\text { upon value chain }\end{array}$ \\
\hline
\end{tabular}

Source: Elaborated by the authors.

Supply chain strategy based upon value net. This form of strategy is based upon the company's capacity of managing the required insights to develop its offering. Therefore, it is necessary to identify which system's participants aggregate more value to customer and, as a result, attract and retain them in order to beneficiate all involved parts.

Innovation strategy based upon value net. Companies that adopt this strategy aim to provide their customers with superior products and services in order to satisfy their specific needs. Hence, the firm, suppliers, customers, and complementors have to join the innovation process.

Customer strategy based upon value net. Players which intend to achieve this strategic positioning seek to establish and fortify their customer relationship. They develop competencies to support the relationship with customers, suppliers, and complementors. Information technology (ERP, CRM, SCM, intranet, extranet, internet, and corporate portals) plays a significant role to help these companies strengthen their relationship with system's participants.

Partner strategy based upon value net. Businesses pursuing this strategy focus their efforts on developing partners which are essential for designing creative and customized solutions. These players usually have vertical organizational structure once their competencies rely on managing the involvement of their partners.

Customer strategy based upon value chain. Companies adopting this strategy aim to satisfy customers' needs through companies' best efforts in order to provide complete and customized offerings. Once the solution is based upon a company's value chain, the solution could be limited to the internal performance which means involving the firm, suppliers, and customers team.

Revista Ibero-Americana de Estratégia - RIAE, São Paulo, v. 9, n. 1, p. 152-181, jan./abr. 2010. 
Strategies Focusing on Value Network: An Analysis of Event Production Companies

Low cost strategy based upon value chain. Players pursuing this strategy focus their competencies to improve their efficiency in order to develop standardized products. It is based upon large scale and internal common platform.

Differentiation strategy based upon value chain. This kind of strategy seeks to provide differentiated solutions to customers with low sensitivity to price. The primary objective of this strategy is to develop a more complete set of products and services through the use of the company's competencies without the collaboration of value chain participants.

\subsection{CLUSTER ANALYSIS}

In order to identify strategic groups within the Sao Paulo event industry, it carried out the cluster K-means analysis for the reduced geographic space which has been formed by the 7 factors previously cited. As a premise for using this proceeding we have assumed that within a cluster there are only businesses pursuing a similar strategy. However, they are entirely separate from firms belonging to other groups.

Table 4 presents clusters' means and the number of companies in each cluster.

Table 4 - Final Clusters Centers.

\begin{tabular}{|c|c|c|c|c|c|}
\hline $\mathrm{n}=$ & 3 & 15 & 4 & 15 & 9 \\
\hline FAC1 & 4,33 & 3,88 & 3,97 & 4 & 5 \\
\hline FAC2 & 3,89 & 3,28 & 3,75 & 4,53 & 4,61 \\
\hline FAC3 & 4,5 & 4,46 & 2,25 & 4,77 & 4,72 \\
\hline FAC4 & 4,67 & 3,66 & 4,44 & 4,6 & 4,61 \\
\hline FAC5 & 4,83 & 3,76 & 4,25 & 4,67 & 4,5 \\
\hline FAC6 & 2,67 & 2,66 & 2,69 & 1,87 & 4,33 \\
\hline
\end{tabular}

Revista Ibero-Americana de Estratégia - RIAE, São Paulo, v. 9, n. 1, p. 152-181, jan./abr. 2010. 
Marcos Roberto Piscopo, Felipe Mendes Borini \& Moacir de Miranda Oliveira Junior

\begin{tabular}{|l|l|l|l|l|l|}
\hline FAC7 & 1,67 & 4,04 & 3,75 & 4,73 & 4,44 \\
\hline
\end{tabular}

Source: Elaborated by the authors.

Finally, in order to explain how firms behave in these clusters and what the relevant factors used to differentiate these businesses strategic positioning are, we carried out a discriminant analysis that led us to 4 functions with prioritized factors (Table 5).

Table 5 - Discriminant Functions.

\begin{tabular}{|c|c|c|c|c|}
\hline \multicolumn{2}{|c|}{ STRUCTURE MATRIX } & & FUNCTION & 4 \\
\hline & 1 & 2 & 3 & 0,364 \\
\hline FAC3 & 0,807 & $-0,058$ & 0,452 & $-0,439$ \\
\hline FAC7 & 0,2 & 0,681 & 0,193 & $-0,144$ \\
\hline FAC6 & $-0,177$ & $-0,185$ & 0,936 & $-0,104$ \\
\hline FAC5 (a) & $-0,037$ & $-0,042$ & $-0,174$ & 0,743 \\
\hline FAC4 & $-0,053$ & 0,211 & 0,131 & 0,5 \\
\hline FAC2 & 0,088 & 0,272 & 0,307 & 0,285 \\
\hline FAC1 (a) & $-0,108$ & $-0,07$ & 0,057 & \\
\hline
\end{tabular}

(a) This variable was not used in the analysis.

Source: Elaborated by the authors.

Cluster 5 comprises companies that focus on keeping low operational costs and standardized activities in order to concentrate their efforts on stimulation, development, and supporting new businesses so as to further add value to their offerings. It is interesting that activities which aggregate high value to a firm's offerings must be performed by external partners. Therefore, the

Revista Ibero-Americana de Estratégia - RIAE, São Paulo, v. 9, n. 1, p. 152-181, jan./abr. 2010. 
main objective of companies pursuing this strategy is to allow their partners to work on innovations. In doing so, these businesses build strong relationships with both their customers and their partners. Hence, these companies assume a central position between their customers and their partners. This strategy is similar to that of companies that adopted the dominant exchange approach to lock-in strategic option of Delta Model.

Companies in cluster 4 mainly adopt customer strategy based upon value net and differentiated services, which can be understood as a clear differentiation based on customized services to satisfy customer needs. This suggests that these companies used to pursue customer intimacy strategy based upon the value chain, and the current competitive environment forced them to be more proactive. Therefore, they assume some activities previously performed by customers in order to perform them more efficiently or effectively than the customer and, as a result, improve customer's economics through cost advantages and higher added value. The strategy adopted by these companies might be associated to the customer integration approach to total customer solutions of Delta Model.

Companies belonging to cluster 2 appear to follow the same strategies that companies belonging to cluster 5 pursue. Nevertheless, firms in cluster 2 have presented lower strategic performance. How can we explain this difference? Following research results it is reasonable to suggest that these companies did not achieve a high level of integration with other system's participants. Another explanation that arises is that these companies are too preoccupied about the costs of their actions. However, as they reached the cluster 5 status, it is essential to acknowledge that customer strategy based upon value net requires high financial investments and a more flexible routine. This clearly illustrates that these firms must fortify the relationship with their partners, as well as, increase their investments in technology which are crucial to support the company's activities.

Firms in cluster 1, in our opinion, should adjust their strategy. These companies have a distinguished position because of their partners strategies based upon value net which fit to the dominant exchange strategy of Delta Model. However, these firms are caught in a dilemma: despite the fact that their focus is on innovation, they do not have the tradition to innovate in order to gain credibility and forward it on to partners whilst also exploring their activities. Therefore, in terms of innovation, companies in cluster 1 achieve a lower strategic performance. On the other hand, rather than focusing on customer integration, they could concentrate efforts on innovation with system's participants. As their performance increases they can be eligible to cluster 5 .

Revista Ibero-Americana de Estratégia - RIAE, São Paulo, v. 9, n. 1, p. 152-181, jan./abr. 2010. 
Marcos Roberto Piscopo, Felipe Mendes Borini \& Moacir de Miranda Oliveira Junior

Finally, firms in cluster 3 also adopt the partner strategy based upon value net; however, they are more focused on innovation aspects related to the value chain. They follow Porter's strategy scheme.

\section{DISCUSSION}

The paper proposes to classify the different forms of strategic approaches focused on either value chain and/or value network. Based approaches were considered in the value chain of the following types: generic competitive strategies (Porter, 1980) definition of business (Abell, 1980); disciplines of value (Wieserma \& Treacy, 1995) and value migration (Slywotzky, 1996). The typologies, according to the article, could be classified as approaches focused on the value chain are strategic triangle (Ohmae, 1980), coopetition (Brandenburger \& Nalebuff, 1996); business scenarios (Ghemawat, 2000) and the model delta of the Hax and Wilde II (2001).

Other than the suggestion of an alternative form of classification, the article hopes contributed to the field of strategy, through practical demonstration of the Delta's model in the Sao Paulo event industry. It was possible to show the application of the model and identify the strategies adopted by companies producing events. Thus, we tried to seek applications for the theories and results of the strategy as pointed out by Bertero, Vasconcelos and Binder (2003).

The application of the delta model (Hax \& Wilde, 2001) emphasizes the contribution of the complements as a way to add greater value to the network. To compete simply by offering superior products and services is an insufficient condition for a company that wants to obtain results above the industry average. The elimination of competitors does not necessarily mean victory in the market, it is essential to understand the role they play in the sector, and to also examine the possibility of having them as collaborators (Tidström, 2006). Prahalad and Ramaswamy (2004) suggest that the future of competition is to create value with customers.

The article allows us to surpass the tradition of the Brazilian studies in the strategy of studying exclusively in the generic strategies of Porter for the units of businesses (Schneider, 2008). The application of the model delta explains the strategic configuration of the firms better in the scenery of current businesses, and it opens doors to new studies focused on the dimensions of the delta model which are still mostly unexplored in the literature (João \& Piscopo, 2006; Toledo et al., 2007; Cozer et al., 2008). New studies looking for delta models metrics can explore perspectives on business strategies that are still linked to the Porter model of thirty years ago (Schneider, 2008).

Revista Ibero-Americana de Estratégia - RIAE, São Paulo, v. 9, n. 1, p. 152-181, jan./abr. 2010. 
Strategies Focusing on Value Network: An Analysis of Event Production Companies

Moreover, when we look at the article in terms of the contribution to event industry, the article contributes to a more specific understanding of the behavior of the industry. Certainly the question of the managing of events is significant and also lacks specific studies, but this research attempted to focus on the strategic management of businesses organizing events. It is expected to have demonstrated the importance of management of events, since events represent elements of social transformation, education, awareness, acculturation, and leverage industries, firms and cities (Melo Neto, 2004).

\section{CONCLUSION}

The purpose of this article was to demonstrate that companies competing within dynamic industries do not solely adopt a single strategy. Instead, they pursue a bundle of strategies focused on the value net rather than on the value chain. Our findings support our hypothesis for the event planning companies based in the City of Sao Paulo. We discovered five distinct groups of firms pursuing different strategies.

The analysis conducted allows us to understand how event planning companies serve the marketplace and their methods to sustain competitive advantages concerning the dynamics of the competitive environment. Although we have classified the strategies adopted by studied companies, we are aware that we can only make assumptions about the evolution of these strategies. Hence, it would be convenient if future research considers the typology utilized in this paper, to concentrate on the evolution of the studied firms' strategies in a longitudinal manner.

We shall enhance the contributions of this study to the management challenges. From our understanding, we would like to highlight two aspects. Firstly, this study did not bring an innovative approach to the strategy formulating process once we have attained from other authors who have studied strategic management. However, this paper brought an innovative perspective about how different typologies can be found and organized in dynamic industries, such as the event planning in City of Sao Paulo. We believe that a firm's main challenge is learning how to adopt different strategic positions based upon both the value net and the value chain in order to conquer and to sustain competitive advantages in dynamic markets.

The second aspect is related to the emphasis we put on strategies based upon value net, especially the Delta Model. Among many different typologies, the Delta Model demonstrates that its strategic options are more appropriated for companies' strategic management. However, just a

Revista Ibero-Americana de Estratégia - RIAE, São Paulo, v. 9, n. 1, p. 152-181, jan./abr. 2010. 
Marcos Roberto Piscopo, Felipe Mendes Borini \& Moacir de Miranda Oliveira Junior

few studies have used this approach. Our work, followed by the results that support our hypothesis, shows how Delta Model by Hax and Wilde II (2001) is useful to explain companies' strategic configuration. We hope this paper stimulates other applications of the Delta Model in other industries in order to better understand its characteristics and verify its effectiveness.

\section{REFERENCES}

Abell, D. F. (1980). Defining the business: the starting point of strategic planning. Englewood Cliffs, New Jersey: Prentice-Hall.

Andrews K. R. (1971). The concept of corporate strategy. Homewood, IL: Dow Jones-Irwin.

Ansoff, H. I. (1965) Corporate strategy: an analytic approach to business policy for growth and expansion. New York: McGraw-Hill.

Brandenburger, A. M., \& Nalebuff, B. J. (1996). Co-opetition. New York: Doubleday.

Chandler, A. D. (1962) Strategy and structure: chapters in the history of the American Industrial Enterprise. Cambridge, MA: MIT Pres.

Cozer, M. T. S., Toledo, G. L., \& Szafir-Goldstein, C. (2008). Laços inter-organizacionais e o posicionamento estratégico de solução total ao cliente do modelo delta - uma pesquisa sobre a díade fornecedor-cliente no B2B. Revista de Administração Mackenzie, 9,163-187.

Dess, G. G., \& Davis, P. S. (1984). Porter's (1980) generic strategies as determinants of strategic group membership and organizational performance. Academy of Management Journal, 27, 467488. http://dx.doi.org/10.2307/256040

Sebrae. (2001). Dimensionamento Econômico da Indústria de Eventos do Brasil. In 1. São Paulo: FBC\&VB - Fórum Brasileiro dos Convention \& Visitors Bureaux: SEBRAE - Serviço Brasileiro de Apoio às Micros e Pequenas Empresas: Consultoria Turística Integrada - CTI, nov.

Drucker, P. F. (1954). The practice of management. New York: Harper \& Brother Publishers.

Goldblatt, J. (2000). A future for event management: the analysis of major trends impacting the emerging profession. In Events Beyond 2000: Setting the Agenda - Event Evaluation, Research and Education Conference Proceedings. J. Allen, R. Harris, L. K. Jago, \& A. J. Veal (Eds.), Australian Centre for Event Management, University of Technology: Sydney.

Revista Ibero-Americana de Estratégia - RIAE, São Paulo, v. 9, n. 1, p. 152-181, jan./abr. 2010. 
Strategies Focusing on Value Network: An Analysis of Event Production Companies

Hall, W. K. (1980) Survival strategies in a hostile environment. Harvard Business Review, 58(5), $75-85$.

Hambrick, D. C. (1983). High profit strategies in mature capital goods industries: a contingency approach. Academy of Management Journal, 26, 687-707.

http://dx.doi.org/10.2307/255916

Hax, A. C. \& Majluf, N. S. (1996). The strategy concept and process: a pragmatic approach. $\left(2^{\text {nd }}\right.$. ed.) Upper Saddle River. New Jersey: Prentice Hall.

Hax, A. C., \& Wilde II, D. L. (2001). The delta project: discovering new sources of profitability in a networked economy. New York: Palgrave.

Hill, C. W. L. (1988). Differentiation versus low cost or differentiation and low cost: A contingency framework. Academy of Management Review, 13, 401-412.

http://dx.doi.org/10.5465/AMR.1988.4306957

http://dx.doi.org/10.2307/258088

Hitt, M. A., Ireland, R. D., \& Hoskisson, R. E. (2001). Strategic management: competitiveness and globalization. Cincinnati, Ohio: South-Western College Publishing.

João, B., \& Piscopo, M. R. (2006). Estratégias de inovação de valor e o modelo delta: o caso zara. eGesta, (Unisantos), 2, p. 1-25.

Jones, G. R., \& Butler, J. E. (1988). Costs, revenue and business-level strategy. Academy of Management Review, 13, 202-13.

http://dx.doi.org/10.5465/AMR.1988.4306865

http://dx.doi.org/10.2307/258572

Kim, L., \& Lim, Y. (1988) Environment, generic strategies and performance in a rapidly developing country: a taxonomic approach. Academy of Management Journal, 31, 802-27.

$\underline{\text { http://dx.doi.org/10.2307/256339 }}$

Lofgren, O. (1999). On holiday, a history of vacationing. Berkeley, California: University of California Press.

Marques, A., Lisboa, J., Zimmerer, T. W., \& Yasin, M. M. (2000) The effectiveness of strategies employed by dominant firms in the Portuguese crystal glass industry: an empirical investigation. European Business Review, 12, 34-40. http://dx.doi.org/10.1108/09555340010307549

Melo Neto, Francisco Paulo de. (1999). Marketing de eventos. (2a. ed.) Rio de Janeiro: Sprint.

Miles, R. E., \& Snow, C. C. (1978). Organizational strategy, structure, and processes. New York: McGraw-Hill.

Revista Ibero-Americana de Estratégia - RIAE, São Paulo, v. 9, n. 1, p. 152-181, jan./abr. 2010. 
Marcos Roberto Piscopo, Felipe Mendes Borini \& Moacir de Miranda Oliveira Junior

Mintzberg, H.; Ahlstrand, B., \& Lampel, J. (2000). Safari de estratégia: um roteiro pela selva do planejamento estratégico. Porto Alegre: Bookman.

Murray, A. (1988). A contingency view of Porter's generic strategies. Academy of Management Review, 13, 390-400. http://dx.doi.org/10.5465/AMR.1988.4306951

Ohmae, K. (1982). The mind of the strategist: the art of japanese business. New York: McGrawHill. 1982.

Pine, B. J., \& Gilmore, J. H. (1999). The experience economy. Boston, Massachusetts: Harvard Business School Press.

Porter, M. E. (1980). Competitive strategy: techniques for analyzing industries and competitors. New York: The Free Press.

Porter, M. E. (1985). The competitive advantage: creating and sustaining superior performance. New York: The Free Press.

Porter, M. E. (1996). What is strategy? Harvard Business Review, XX, 61-78.

Prahalad, C. K., \& Ramaswamy, V. (2004). O futuro da competição: como desenvolver diferenciais inovadores em parceria com os clientes. Rio de Janeiro: Elsevier.

Rumelt, R. P. (1974). Strategy, structure, and economic performance. (2a. ed.). Boston: Harvard Business School Press.

Slywotzky, A. J. (1996). Value migration: how to think several moves ahead of the competition. Boston, Massachusetts: Harvard Business School Press.

Tidistrom, A., \& Åhman, S. (2006) The process of ending interorganizational cooperation. The Journal of Business and Industrial Marketing, 5, 281-291. http://dx.doi.org/10.1108/08858620610681588

Toledo, G. L., Pollero, A.C., \& Quelopana, E. M. (2007). Posicionamento estratégico e liderança em mercado globalizado o caso de uma holding latino-americana líder em P\&D\&I. O\&S. Organizações \& Sociedade, 14, 135-159.

Treacy, M., \& Wieserma, F. (1995). The discipline of market leaders. Reading, Mass: AddisonWesley.

White, R. E. (1986). Generic business strategies, organizational context and performance: an empiric investigation. Strategic Management Journal, 7, 217-231.

http://dx.doi.org/10.1002/smj.4250070304

Revista Ibero-Americana de Estratégia - RIAE, São Paulo, v. 9, n. 1, p. 152-181, jan./abr. 2010. 
Strategies Focusing on Value Network: An Analysis of Event Production Companies

Zanella, L.C. (2003). Manual de organização de eventos: planejamento e operacionalização. São Paulo: Atlas.

Recebido: 05/01/2010

Aprovado: 25/03/2010

Revista Ibero-Americana de Estratégia - RIAE, São Paulo, v. 9, n. 1, p. 152-181, jan./abr. 2010. 